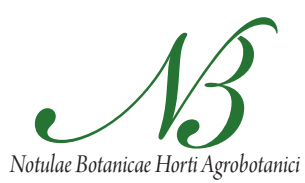

Cluj-Napoca

\title{
Genetic Differentiation between Quercus frainetto Ten. and Q. pubescens Willd. in Romania
}

\author{
Alexandru Lucian CURTU, Ioan Calin MOLDOVAN, Cristian Mihai \\ ENESCU, Iacob CRACIUNESC, Nicolae SOFLETEA \\ Transilvania University Brasov, Dept. of Forest Sciences Sirul Beethoven-1, Brasov-500123, Romania; lucian.curtu@unitbv.ro
}

\begin{abstract}
Little is known about genetic differences among Quercus frainetto and Q. pubescens, two species of section Dascia Kotschy (subgenus Lepidobalanus, white oaks) that reach in Romania the margins of their natural distribution range. A set of genomic SSRs (simple sequence repeats) and EST (expressed sequence tags)-SSRs was used to estimate the genetic differentiation among four natural populations of the two species. Q. pubescens had higher values of genetic diversity than $Q$. frainetto, although the differences were not significant $(\mathrm{P}>0.05)$. Two out of seven marker-loci, QrZAG112 and QpZAG110, displayed very high $\mathrm{F}_{S \mathrm{~T}}$ values. Averaged across loci, the genetic differentiation was high and significant $\left(\mathrm{F}_{S T}=0.067, \mathrm{P}<0.05\right)$. Genetic distances were much higher among species than among populations within species. A Bayesian analysis indicated that two is the most appropriate number of genetic clusters. Using a blind procedure (i.e. based on multilocus genotypes only) the vast majority of sampled individuals (90\%) could be assigned to the cluster corresponding to their phenotypes. When information about sampling localities was introduced in the assignment test, all individual trees were correctly classified. The higher degree of admixture in Q. frainetto as compared to Q. pubescens may be explained by different rates of introgressive hybridization.
\end{abstract}

Keywords: expressed sequence tags (EST), genetic differentiation, oaks, Quercus frainetto, Quercus pubescens, simple sequence repeats (SSRs)

\section{Introduction}

The issue of genetic differentiation among closely related species is a central research theme because it provides insights into the evolutionary processes responsible for species divergence. Genus Quercus is a long-standing model for studying population divergence, species delimitation and natural hybridization (e.g. Curtu et al., 2009; Gailing et al., 2007; Peñaloza-Ramírez et al., 2010; Zeng et al., 2010). In Europe, most of the studies have focused on genetic differentiation and identification of highly discriminating genomic regions between the most common oak species: Q. robur and Q. petraea (Jensen et al., 2009; Muir and Schlötterer, 2005; Neophytou et al., 2010; Scotti-Saintagne et al., 2004). By contrast, little is known about genetic differences between the two oak species from Section Dascia Kotschy (subgenus Lepidobalanus or white oaks), Q. frainetto and Q. pubescens, although they have a high ecological and economic value in the southeastern part of the European continent (Abrudan et al., 2009; Ioras et al., 2009).

The actual distribution of Q. frainetto in Romania comprises approximately 130000 ha, $2 \%$ of the total forest cover, as much as Q. robur (Sofletea and Curtu, 2007). Q. frainetto and Q. pubescens are elements of the (sub-)Mediterranean flora that reach in Romania the northern limit of their distribution range. Q. frainetto is a meso-xerophilous species which can grow on heavy clay soils. Q. pubescens is better adapted to xeric conditions, being found on dry sites, such as on limestones and sunny slopes (e.g. in Transylvania) or in the wood steppe in southern Romania. Both species can be easily identified using leaf and fruit characters (Schwarz, 1993).

Few studies have investigated genetic differences between Q. frainetto and Q. pubescens, or between them and other oak species. Chloroplast DNA markers were found to be polymorphic, but could not discriminate among species (Moldovan et al., 2010; Petit et al., 2002). Highly polymorphic nuclear markers, such as microsatellites (SSRs -simple sequence repeats), are more promising for differentiating among oak species (Curtu et al., 2007; Fortini et al., 2009). Very recently, microsatellite markers have been developed from expressed sequence tags (EST) or sequences of messenger RNA starting from a $Q$. robur/Q. petraea library (Durand et al., 2010). In contrast to genomic SSRs, EST-SSRs have the advantage of being located within the expressed portion of the genome, and thus reflect differences at gene level.

The aim of this study was to estimate the genetic differentiation between the two oak species of section Dascia that occur in Romania. It was tested whether genotypic information from a set of seven microsatellite markers is 
276

sufficient to identify the species at population and individual level.

\section{Materials and methods}

\section{Sampling strategy}

Two populations for each species, Q.pubescens and $Q$. frainetto, were selected at four sites across Romania. Collections were made in 2010 from adult individuals at MăcinTulcea $\left(45^{\circ} 13^{\prime} \mathrm{N}, 28^{\circ} 14^{\prime} \mathrm{E}\right)$ and Săcălaia-Cluj $\left(46^{\circ} 57^{\prime} \mathrm{N}\right.$, $23^{\circ} 56^{\prime} \mathrm{E}$ ) for Q. pubescens, and Seaca Optășani-Olt $\left(44^{\circ} 43^{\prime} \mathrm{N}, 24^{\circ} 28^{\prime} \mathrm{E}\right)$ and Lugoj-Timis $\left(45^{\circ} 43^{\prime} \mathrm{N}, 21^{\circ} 59^{\prime} \mathrm{E}\right)$ for $Q$. frainetto. The total number of trees sampled was 125: 62 Q. pubescens individuals (32 at Măcin-Tulcea and 30 at Săcălaia-Cluj) and 63 Q. frainetto individuals (31 at Seaca Optășani-Olt and 32 at Săcălaia-Cluj). Habitat data and GPS mapping data were collected at each site. Species identification was carried out following Sofletea and Curtu (2007).

\section{Genetic analysis}

DNA was extracted from buds using the Qiagen DNeasy96 Plant Kit following the manufacturer protocol, but without liquid nitrogen for material disruption. The DNA was then kept by $-60^{\circ} \mathrm{C}$ until use. Five genomic SSRs (gSSRs) and two EST-SSRs were amplified using Polymerase Chain Reaction (PCR). Both gSSRs (Kampfer et al., 1998; Steinkellner et al., 1997) and EST-SSRs (Durand et al., 2010) were developed from Q. robur/Q. petraea libraries. More information about the primer pairs, repeat motif and allele length is given in Tab. 1 . The forward primer for each locus was fluorescently labelled with Beckman dyes (D2, D3 and D4). The primers were combined into two PCR multiplexes on the basis of annealing temperature and fluorescent label. The first multiplexing reaction included the five gSSRs and the second one the two EST-SSRs. The reactions were performed in a $20 \mu \mathrm{l}$ volume containing approximately $10 \mathrm{ng}$ template DNA; 1x Promega colorless PCR buffer; $2 \mathrm{mM}$ of $\mathrm{MgCl}_{2} ; 0.45$ $\mathrm{mM}$ of each dNTP (Fermentas); for each primer concentrations see Tab. 1; 1.15 U Taq DNA polymerase (Promega). Amplification was carried out in a Corbett Thermal Cycler. The PCR profile was as follows: 3 minutes of denaturation at $94^{\circ} \mathrm{C}$ followed by 31 cycles of $50 \mathrm{~s}$ denaturation at $94^{\circ} \mathrm{C}$, a $40 \mathrm{~s}$ annealing step at $52^{\circ} \mathrm{C}$ for gSSRs $\left(57^{\circ} \mathrm{C}\right.$ for EST-SSRs), a $1 \mathrm{~min} 20 \mathrm{~s}$ elongation step at $70^{\circ} \mathrm{C}$ and a final extension step at $70^{\circ} \mathrm{C}$ for $12 \mathrm{~min}$. Amplification products were run on a Beckman Coulter Genetic Analyser using Frag-3 method and Size Standard 400. The products were then analyzed using Fragment Analysis Software using default parameters and PA ver1 dye correction.

\section{Statistical data analysis}

Microsatellite loci were tested for genotyping errors due to non-amplified alleles, large allele drop-out and scoring of stutter peaks using MICRO-CHECKER 2.2.0.3 (Van Oosterhout et al., 2004). For each microsatellite locus and species, number of alleles, number of species-specific alleles, allele frequencies, observed and expected heterozygosity (gene diversity), unbiased estimates of Nei's genetic distances were calculated using the computer software GenAlEx version 6.4 (Peakall and Smouse, 2006). Using FSTAT version 2.9.3.2 (Goudet, 1995), allelic richness (El Mousadik and Petit, 1996; Petit et al., 1998), a measure of the number of alleles that is independent of the sample size, was calculated. The smallest number of the individuals (n) for a locus (QrZAG39) in a species was set to 43. The differences between species were tested using a Student's $t$-test. An unweighted pair group method arithmetic average (UPGMA) dendrogram of the oak populations, based on Nei's genetic distance, was constructed using MEGA version 4 (Tamura et al., 2007).

A hierarchical Analysis of Molecular Variance (AMOVA) using the program ARLEQUIN ver 3.5.1.2 (Excoffier et al., 2005) was employed to examine the partitioning of molecular variance into components: within populations, among populations within species and among species. $\mathrm{F}_{S \mathrm{~T}}$ values were estimated for each locus and across loci. $\mathrm{F}_{S T}$ values were tested by permuting individual genotypes among populations and species. P-values were calculated using 10000 permutations.

The frequency-based assignment test (Paetkau et al., 1995) available in GenAlEx v. 6.4 software was first used to assign individuals to species. For each individual, a log likelihood value was calculated for each species, using the allele frequencies of the respective species. An individual was assigned to the species with the highest log likelihood value.

Tab. 1. Characteristics of the seven investigated loci

\begin{tabular}{|c|c|c|c|c|c|c|}
\hline Type of marker & Locus & Nucleotide motif & $\begin{array}{c}\text { Linkage } \\
\text { group (LG) }\end{array}$ & $\begin{array}{c}\text { Beckman } \\
\text { Dye }\end{array}$ & $\begin{array}{l}\text { Primer concentration } \\
(\mu \mathrm{M})\end{array}$ & $\begin{array}{l}\text { Allele size } \\
\text { (bp) }\end{array}$ \\
\hline \multirow{5}{*}{$\begin{array}{l}\text { Genomic SSRs } \\
\quad(\text { gSSRs })\end{array}$} & QrZAG11 & $\mathrm{di}$ & 10 & D3 & 0.34 & $242-289$ \\
\hline & QrZAG39 & di & 5 & D2 & 0.28 & $105-169$ \\
\hline & QrZAG96 & $\mathrm{di}$ & 10 & D3 & 0.25 & $140-180$ \\
\hline & QpZAG110 & di & 8 & D4 & 0.18 & $205-243$ \\
\hline & QrZAG112 & di & 12 & D4 & 0.09 & $82-112$ \\
\hline \multirow{2}{*}{ EST-SSRs } & GOT004 & di & 2 & D4 & 0.20 & $266-306$ \\
\hline & PIE040 & tri & - & D3 & 0.33 & $171-190$ \\
\hline
\end{tabular}


The Bayesian clustering method implemented in STRUCTURE software version 2.3.3 (Pritchard et al., 2000) was further used to determine the genetic structure of the sampled populations. Two model approaches have been used. The first approach was a blind procedure that did not use any prior information about species and geographic location. The second one took into consideration the sampling location (with LocPrior model). This model is recommended when molecular data is not very informative to help the detection of population structure (Hubisz et al., 2009). 20 independent runs were done for K, number of clusters, ranging from 1 to 5 . The program was run with correlated allele frequency (Falush et al., 2003). Each run consisted in 50000 burn-in steps followed by $10^{6}$ iterations. To estimate the number of clusters $(\mathrm{K})$, an $a d$ hoc measure, $\Delta K$, which is based on the rate of change in the 'log probability of data' $(\mathrm{L}(K))$ between successive $\mathrm{K}$ values, was calculated (Evanno et al., 2005). The software STRUCTURE HARVESTER (Earl, 2011) was used for $\Delta K$ estimation.

\section{Results and discussion}

The seven genomic SSR and EST-SSR markers have revealed high levels of polymorphism in both species (Tab. 2). However, a strong reduction in variability was observed at two genomic dinucleotide microsatellite loci, QrZAG112 and QpZAG110, in Q. frainetto. The two oak species share the most frequent alleles at the investigated loci. Nevertheless, numerous species-specific alleles (i.e. alleles that are found only in each population of one species) were also observed, but the vast majority of them are rare (relative frequency $<0.05$ ). Most of the rare alleles may simply be species-specific because of the limited sample size. Allelic richness is highly sensitive to sampling errors, especially at highly polymorphic microsatellite markers (Litt and Luty, 1989). Only five Q. pubescens and two Q. frainetto specific alleles with higher frequency $(>0.05)$ were detected in the four oak populations. Allele 92bp (Fig. 1a) at locus QrZAG112 (frequency=0.17) and allele 245bp at locus QrZAG11 (frequency=0.10) are among the five specific allele for Q.pubescens. By contrast, Q. frainetto specific alleles have been detected in the EST regions: allele 184bp at locus PIE040 (frequency=0.10) and allele 304bp (frequency $=0.06$ ) at locus GOT004.

No evidence for scoring errors due to stuttering and large allele drop-out was found in the microsatellite data set. However, Micro-checker software indicated that null (non-amplified) may be present at two marker-loci: QrZAG39 and GOT004. Interestingly, null alleles were also reported at locus QrZAG39 in Q. robur and Q.petraea (Neophytou et al., 2010). The high number of alleles detected at locus GOT004 (see Tab. 2) which differs only 1 base pairs (bp) in length, although the repeat motif is dinucleotide (TG), supports the assumption of high mutation rates in the flanking regions of the microsatellite sequence including the primer's binding site.

Mean values of genetic diversity measures were higher in Q. pubescens than in Q. frainetto, but the differences are not significant $(\mathrm{P}>0.05)$ (Tab. 2). Higher allelic richness and gene diversity in $Q$. pubescens might be explained by the greater propensity of this species to hybridize with other white oak species (Q. petraea, Q. robur) as compared to $Q$. frainetto. Indeed, in a four-oak-stand (Bejan-Deva) in west-central Romania, there was evidence for more hybrids between Q.pubescens and the three other species than hybrids that have Q. frainetto as parental species (Curtu et al., 2007). Some hybrid combinations that involve $Q$. frainetto, such as $Q$. frainetto $\times$ Q. robur, were extremely rare in the same mixed stand. Since $Q$. pubescens and Q. frainetto have very similar proportions in the Bejan Forest, the differences in the hybridization rates were not influenced by their relative abundance (Lepais et al., 2009). Therefore, the reproductive barriers seemed to be stronger in $Q$. frainetto than in Q. pubescens. Moreover, Q. pubescens hybridizes extensively with Q.petraea in other parts of the natural range (e.g. in Italy, Salvini et al., 2008).

Two out of seven loci displayed very high $\mathrm{F}_{S T}$ values (Tab. 3). The two loci are genomic SSRs markers. However, one of the EST-SSR loci, PIE004, also shows a relatively high $\mathrm{F}_{S T}$ value. Interestingly, locus QrZAG112 (Fig. 1) discriminated also very well between $Q$. petraea and $Q$. robur (Scotti-Saintagne et al., 2004). Not the same situation was found for another outlier locus between Q. pe-

Tab. 2. Diversity measures of the seven microsatellite loci investigated in Q. pubescens (PUB) and Q. frainetto (FRA)

\begin{tabular}{|c|c|c|c|c|c|c|c|c|}
\hline \multirow{2}{*}{ Locus } & \multicolumn{2}{|c|}{$\mathrm{N}$} & \multicolumn{2}{|c|}{ A } & \multicolumn{2}{|c|}{$\mathrm{H}_{0}$} & \multicolumn{2}{|c|}{$\mathrm{H}$} \\
\hline & PUB & FRA & PUB & FRA & PUB & FRA & PUB & FRA \\
\hline QrZAG11 & 18 & 10 & 17.1 & 9.0 & 0.755 & 0.545 & 0.844 & 0.610 \\
\hline QrZAG39 & 21 & 21 & 20.1 & 21.0 & 0.796 & 0.744 & 0.929 & 0.922 \\
\hline QrZAG96 & 20 & 17 & 19.6 & 16.2 & 0.880 & 0.855 & 0.929 & 0.903 \\
\hline QpZAG110 & 15 & 12 & 14.4 & 11.3 & 0.788 & 0.474 & 0.853 & 0.462 \\
\hline QrZAG112 & 11 & 5 & 10.7 & 4.6 & 0.810 & 0.194 & 0.819 & 0.181 \\
\hline GOT004 & 24 & 25 & 23.8 & 23.4 & 0.844 & 0.857 & 0.937 & 0.940 \\
\hline PIE040 & 10 & 12 & 9.9 & 10.9 & 0.739 & 0.732 & 0.701 & 0.686 \\
\hline Average & 17.0 & 14.6 & 16.5 & 13.8 & 0.802 & 0.629 & 0.859 & 0.672 \\
\hline
\end{tabular}

Note: $\mathrm{Na}$-number of alleles, A - allelic richness after rarefaction ( $\mathrm{n}=43$ individuals), Ho - observed heterozygosity, He - expected heterozygosity. 


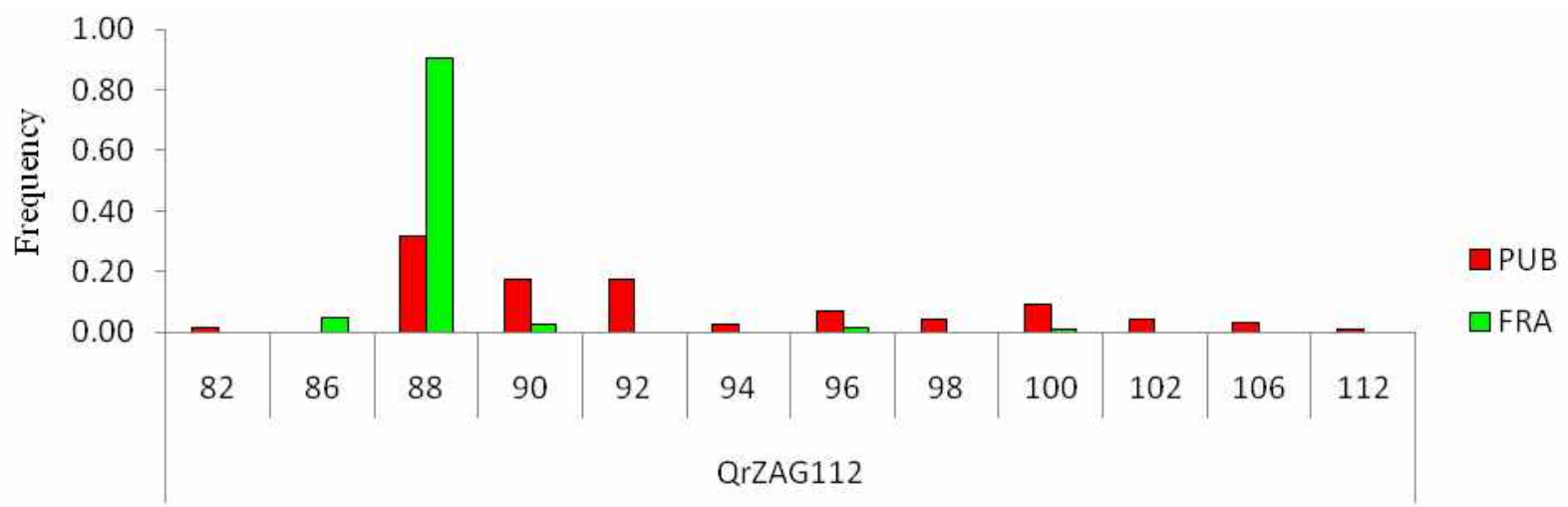

a

Allele size (bp)

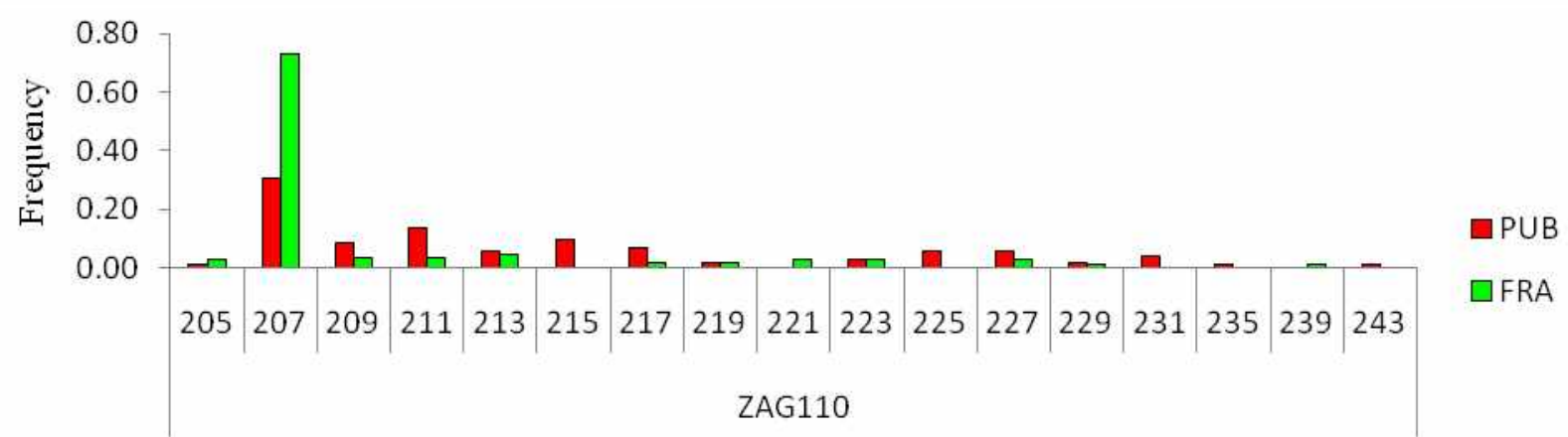

b

Allele size (bp)

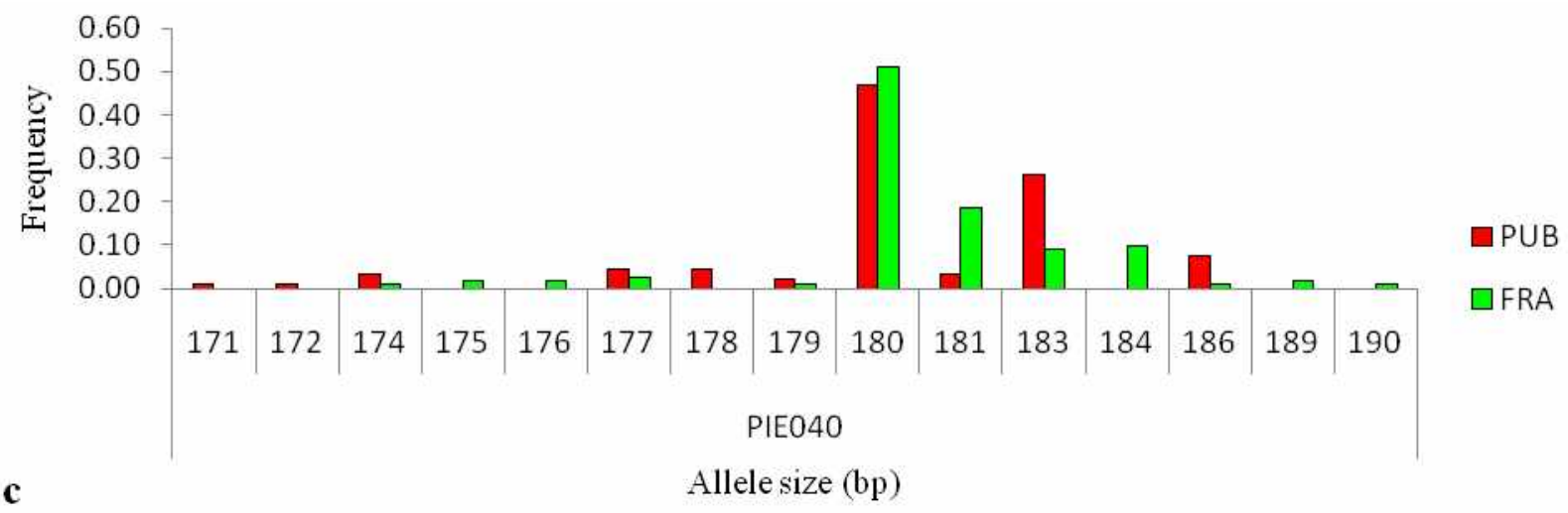

Fig. 1. Allele frequency spectra at loci with high FST values: genomic SSRs (a and b) and EST-SSRs (c). Abbreviations: PUB - Q. pubescens, FRA - Q. frainetto, bp - base pairs

Tab. 3. Pairwise $\mathrm{F}_{\mathrm{ST}}$ values between $Q$. pubescens and $Q$. frainetto for the seven microsatellite loci

\begin{tabular}{ccc}
\hline Locus & $\mathrm{F}_{\mathrm{ST}}$ value & P value $(10000$ replicates $)$ \\
\hline QrZAG112 & 0.290 & 0.00 \\
QpZAG110 & 0.130 & 0.00 \\
QrZAG11 & 0.049 & 0.00 \\
PIE040 & 0.041 & 0.00 \\
GOT004 & 0.010 & 0.01 \\
QrZAG96 & 0.009 & 0.02 \\
QrZAG39 & 0.002 & 0.43 \\
All & 0.067 & 0.00 \\
\hline
\end{tabular}

traea and Q. robur (QrZAG96) that shows an extremely low value for $\mathrm{F}_{\mathrm{ST}}$ in the present investigation (Tab. 3). Loci with high $\mathrm{F}_{\mathrm{ST}}$ values are very likely situated in genomic regions under selection (Lexer et al., 2006; Neophytou et al., 2010; Scotti-Saintagne et al., 2004). Genetic differentiation between both species was high and significant $\left(\mathrm{F}_{\mathrm{ST}}=0.067 ; \mathrm{P}<0.05\right)$, when all loci where considered jointly. Significant differences between $Q$. frainetto and $Q$. pubescens were also reported for a set of five genomic SSRs in Italy (Fortini et al., 2009).

The four populations cluster according to species rather than geographic origin (Fig. 2). The genetic distance 

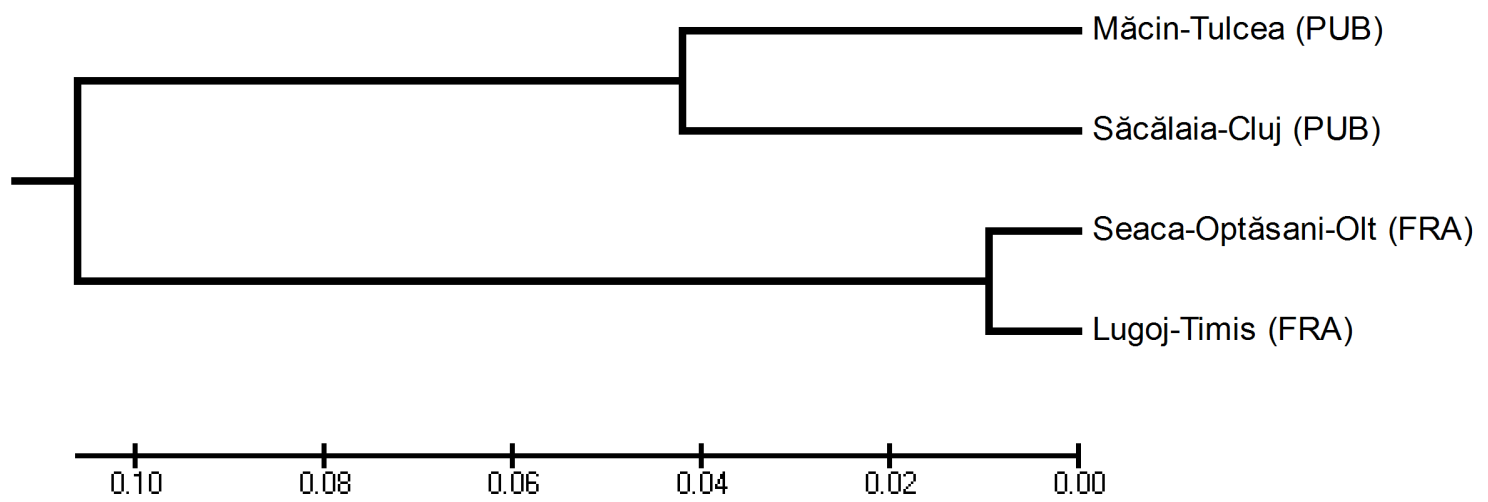

Fig. 2. UPGMA dendrogram based on unbiased estimates of Nei's genetic distances between Q.pubescens (PUB) and Q. frainetto (FRA) populations at seven microsatellite loci

Percentages of Molecular Variance

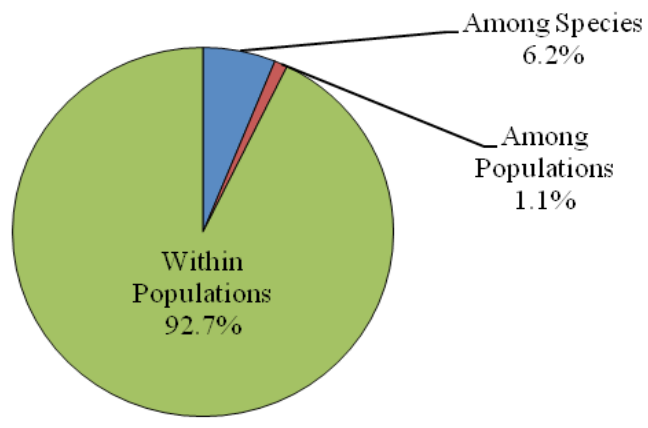

Fig. 3. Results of Analysis of Molecular Variance (AMOVA) among $Q$. frainetto populations is much smaller than that among $Q$. pubescens populations, which is consistent with the geographic distances among populations. Moreover, in accordance with AMOVA, the genetic variation among Q. pubescens and Q. frainetto is nearly six fold higher than the variation among populations within species (Fig. 3).

Using a genetic assignment procedure implemented in software GenAlEx ver. 6.4., the taxonomic status of the sampled individuals, that had either a $Q$. pubescens or $Q$. frainetto phenotype, was determined. In $96 \%$ of the cases, the molecular data indicated the correct status (Fig. 4). Only five individuals, four Q. pubescens and one Q. frainetto, were not correctly assigned. In the Bayesian analysis, the uppermost level of structure corresponds to two clusters (Fig. 5). Each species was represented by one cluster

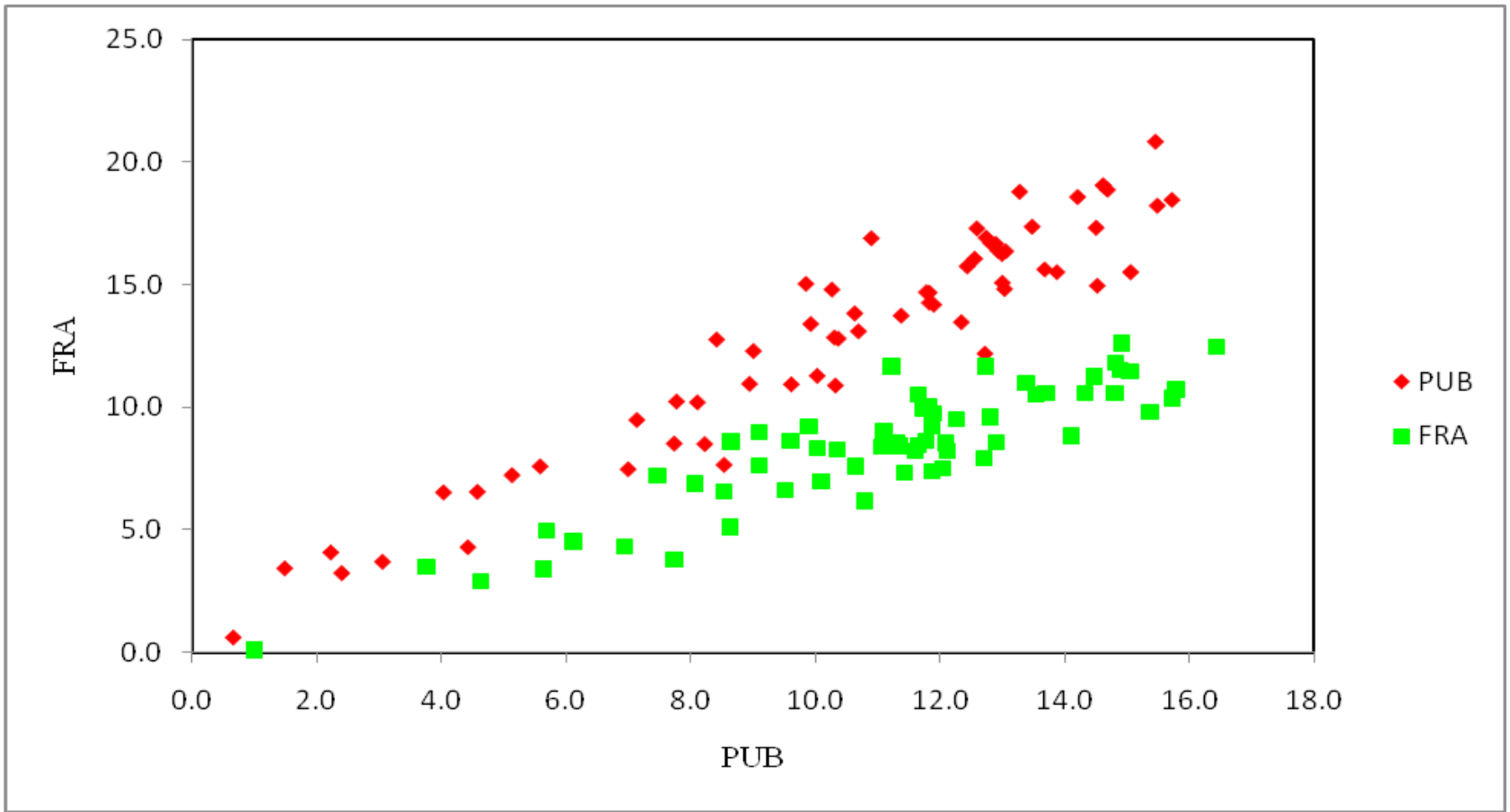

Fig. 4. Genetic assignment of Q. pubescens (PUB ) and Q. frainetto (FRA) samples by using the frequency-based test implemented in the software GenAlEx ver. 6.4 

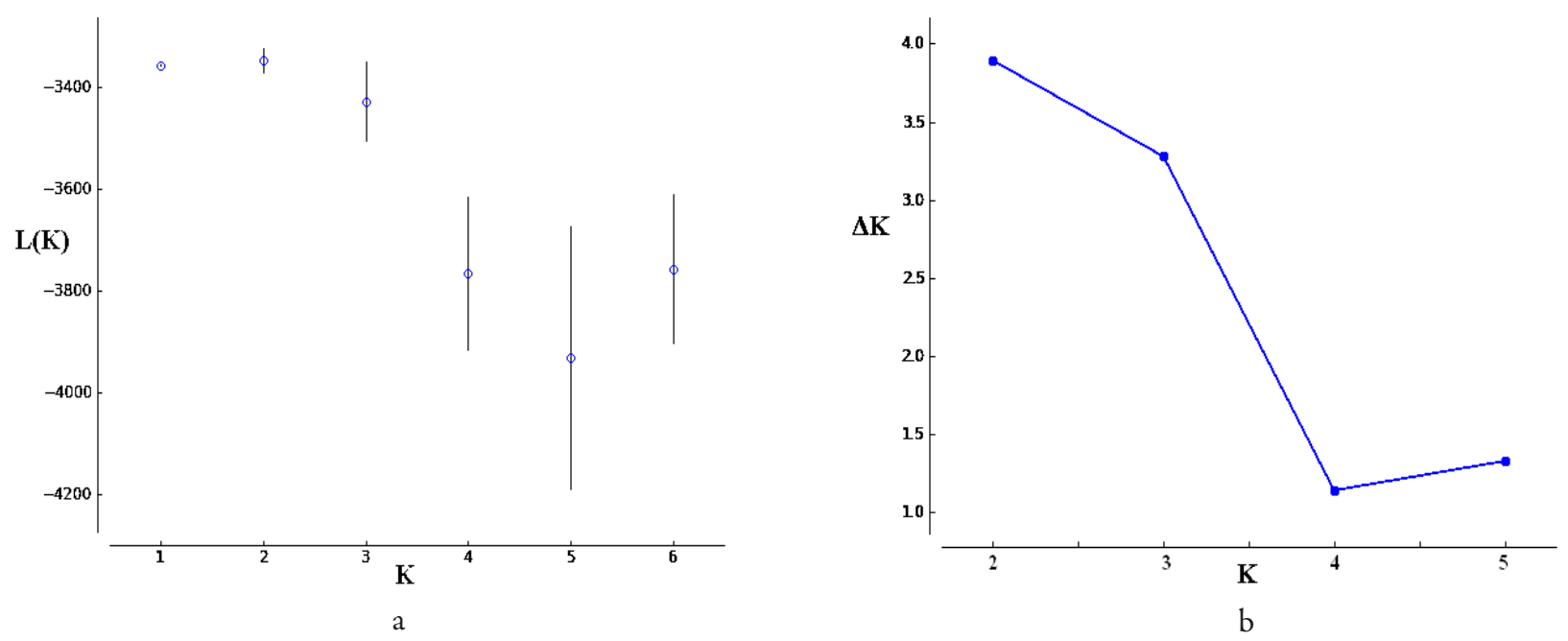

Fig. 5. a - Mean $\mathrm{L}(\mathrm{K})( \pm \mathrm{SD})$ over 20 runs for each $\mathrm{K}$ value; $\mathrm{b}-\Delta \mathrm{K}$ calculated as $\Delta \mathrm{K}=\mathrm{m}|\mathrm{L} "(\mathrm{~K})| / \mathrm{s}[\mathrm{L}(\mathrm{K})]$. The modal value of this distribution is the true $\mathrm{K}$ or the uppermost level of structure, here two clusters

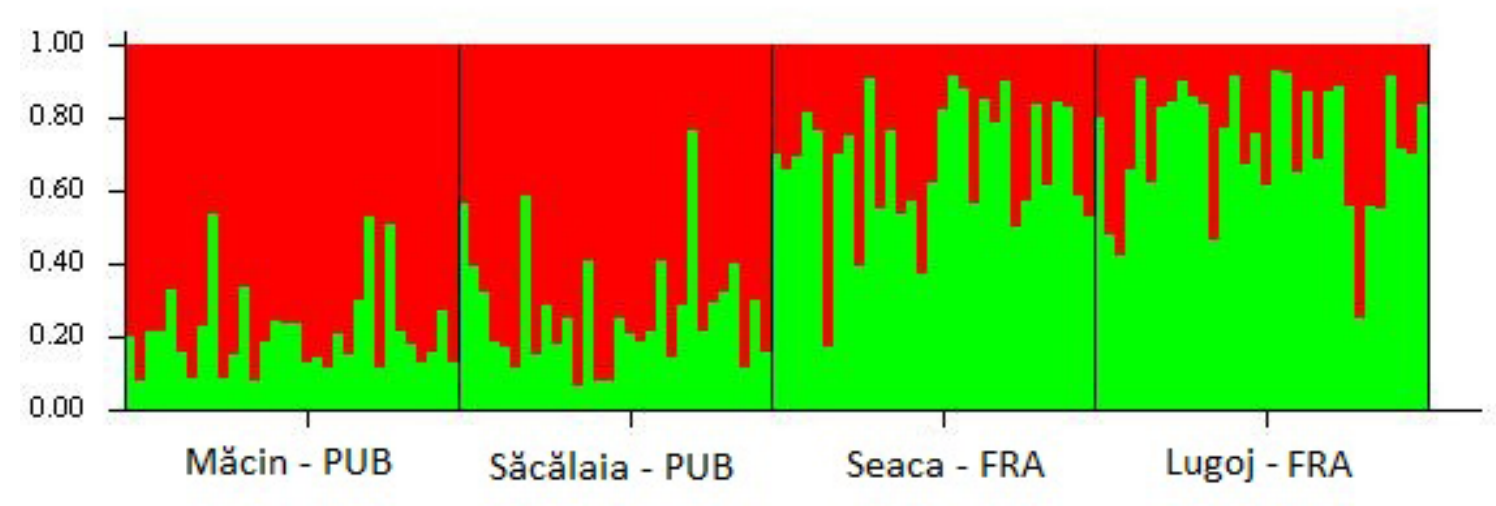

a

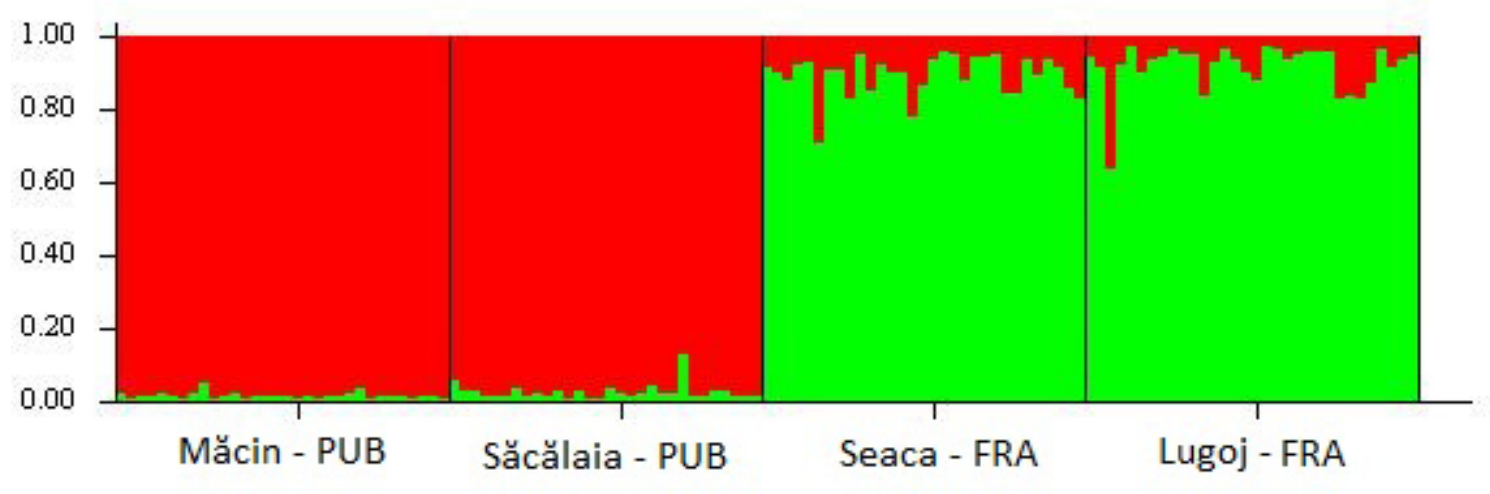

b

Fig. 6. Structure clustering results obtained for $\mathrm{K}=2$ clusters with: $\mathrm{a}$ - no prior information, $\mathrm{b}$ - LocPrior model. Each individual is represented by a thin vertical bar partitioned into two color segments proportional to its membership in each genetic cluster. The four populations of Q.pubescens (PUB) and Q. frainetto (FRA) are separated by black lines and identified at the bottom

and the admixture coefficient (Q), corresponding to the assignment probability of each individual to each cluster, was used to infer the species status. There was a clear correspondence between the genetic cluster and the species designation (Fig. 6). When no prior information was used in the assignment procedure, $90 \%$ of the individuals had the highest admixture coefficient $(Q>0.50)$ for the genetic group corresponding to their phenotype (Fig. 6a). The percentage reaches $100 \%$ if information about the sampling localities is considered in the admixture model (Fig. 6b). 
Among the individuals that were not correctly classified (10\%) using the blind procedure, no one had a probability larger than 0.85 for the wrong cluster. Most of them had coefficients of admixture between 0.50 and 0.60 , a proportion which usually correspond to hybrids, although only pure stands for both species have been sampled. Two hypotheses may explain the wrong assignment of the 13 individuals: (1) the molecular data was not informative or (2) these individuals are natural hybrids. The first hypothesis is supported by the absence (at Săcălaia-Cluj) and low-density (at Măcin-Tulcea) of Q. frainetto individuals in the vicinity of the two $Q$. pubescens populations. Moreover, closely related oak species, which have recently diverged, share ancestral polymorphism (Muir and Schlötterer, 2005). On the other hand, hybridization events are more likely in the two Q. frainetto stands since Q. pubescens populations are mentioned to occur in their proximity (Sofletea and Curtu, 2007). Indeed, the degree of admixture was larger for $Q$. frainetto populations than for $Q$. pubescens populations ( 0.30 versus 0.25$)$, which suggests more introgression in Q. frainetto. However, hybridization by long distance pollen dispersal may explain the occurrence of hybrids between the two species in apparently isolated $Q$. pubescens populations. The same hypothesis was invoked for the presence of hybrids with Q. pyrenaica and $Q$. pubescens in a mixed stand consisting only of $Q$. robur and $Q$. petraea trees, although the nearest $Q$.pyrenaica and Q. pubescens populations are localised tens of kilometres away (Lepais et al., 2009).

\section{Conclusions}

Higher values of genetic diversity measures were observed in Q.pubescens than in Q. frainetto. Two out of seven microsatellite loci discriminated very well between the two species. The molecular analysis demonstrates that $Q$. pubescens and $Q$. frainetto can be unambiguously designated at population level. Using seven microsatellite markers the species of an individual can be easily identified when sampling location is known. In the absence of any information about geographical location, the species can still be determined with a high probability.

\section{Acknowledgements}

This work was supported by CNCSIS-UEFISCDI, project number PN II-RU-TE-73/2010. IC Moldovan, $\mathrm{CM}$ Enescu, and I Crăciunescu were supported by the Sectoral Operational Programme Human Resources Development (SOP HRD), 6/1.5/S/6, 88/1.5/S/59321, and ID76945, financed from the European Social Fund and by the Romanian Government. We wish to also thank an anonymous reviewer for valuable comments on an earlier version of the manuscript. We are grateful to Viorel Roșca, park director, and Bogdan Băjenariu, biologist at the National Park "Munții Măcinului", for allowing us to collect samples of Quercus pubescens. We thank Andras Tothpal for his help during the field work.

\section{References}

Abrudan IV, Marinescu V, Ionescu O, Ioras F, Horodnic SA, Sestras R (2009). Developments in the Romanian forestry and its linkages with other sectors. Notulae Botanicae Horti Agrobotanici Cluj 37(2):14-21.

Curtu AL, Gailing O, Finkeldey R (2007). Evidence for hybridization and introgression within a species-rich oak (Quercus spp.) community. BMC Evolutionary Biology 7:218.

Curtu AL, Gailing O, Finkeldey R (2009). Patterns of contemporary hybridization inferred from paternity analysis in a four-oak-species forest. BMC Evolutionary Biology 9(1):284.

Durand J, Bodenes C, Chancerel E, Frigerio J-M, Vendramin G, Sebastiani F, Buonamici A, Gailing O, Koelewijn H-P, Villani F, Mattioni C, Cherubini M, Goicoechea P, Herran A, Ikaran Z, Cabane C, Ueno S, Alberto F, Dumoulin P-Y, Guichoux E, de Daruvar A, Kremer A, Plomion C (2010). A fast and cost-effective approach to develop and map EST-SSR markers: oak as a case study. BMC Genomics 11(1):570.

Earl DA (2011). Structure harvester v0.6. Available at http:// taylor0.biology.ucla.edu/struct_harvest/.

El Mousadik A, Petit RJ (1996). High level of genetic differentiation for allelic richness among populations of the argan tree [Argania spinosa (L.) Skeels] endemic to Morocco. TAG Theoretical and Applied Genetics 92(7):832-839.

Evanno G, Regnaut S, Goudet J (2005). Detecting the number of clusters of individuals using the software structure: a simulation study. Molecular Ecology 14(8):2611-2620.

Excoffier L, Laval G, Schneider S (2005). Arlequin (version 3.0): An integrated software package for population genetics data analysis. Evolutionary Bioinformatics Online 1:47-50.

Falush D, Stephens M, Pritchard JK (2003). Inference of population structure using multilocus genotype data: linked loci and correlated allele frequencies. Genetics 164(4):15671587.

Fortini P, Viscosi V, Maiuro L, Fineschi S, Vendramin GG (2009). Comparative leaf surface morphology and molecular data of five oaks of the subgenus Quercus Oerst (Fagaceae). Plant Biosystems 143(3):543-554.

Gailing O, Wachter H, Schmitt H-P, Curtu AL, Finkeldey $R$ (2007). Characterization of different provenances of Slavonian oaks (Quercus robur L.) in Münsterland (Germany) with chloroplast DNA markers: PCR-RFLPs and chloroplast microsatellites. Allgemeine Forst und Jagdzeitung 178(5/6):85-90.

Goudet J (1995). FSTAT (Version 1.2): A Computer Program to Calculate F-Statistics. Journal of Heredity 86(6):485486. 
282

Hubisz MJ, Falush D, Stephens M, Pritchard JK (2009). Inferring weak population structure with the assistance of sample group information. Molecular Ecology Resources $9(5): 1322-1332$.

Ioras F, Abrudan IV, Dautbasic M, Avdibegovic M, Gurean D, Ratnasingam J (2009). Conservation gains through HCVF assessments in Bosnia-Herzegovina and Romania. Biodiversity and Conservation 18(13):3395-3406.

Jensen J, Larsen A, Nielsen LR, Cottrell J (2009). Hybridization between Quercus robur and Q. petraea in a mixed oak stand in Denmark. Annals of Forestry Science 66(7):706.

Kampfer S, Lexer C, Glössl J, Steinkellner H (1998). Characterization of (GA)n microsatellite loci from Quercus robur. Hereditas 129:183-186.

Lepais O, Petit RJ, Guichoux E, Lavabre JE, Alberto F, Kremer A, Gerber S (2009). Species relative abundance and direction of introgression in oaks. Molecular Ecology 18(10): 22282242.

Lexer C, Kremer A, Petit RJ (2006). Shared alleles in sympatric oaks: recurrent gene flow is a more parsimonious explanation than ancestral polymorphism. Molecular Ecology 15(7):2007-2012.

Litt M, Luty JA (1989). A hypervariable microsatellite revealed by invitro amplification of a dinucleotide repeat within the cardiac-muscle actin gene. American Journal of Human Genetics 44(3):397-401.

Moldovan IC, Sofletea N, Curtu AL, Abrudan IV, Postolache D, Popescu F (2010). Chloroplast DNA diversity of oak species in Eastern Romania. Notulae Botanicae Horti Agrobotanici Cluj 38(3):301-307.

Muir G, Schlötterer C (2005). Evidence for shared ancestral polymorphism rather than recurrent gene flow at microsatellite loci differentiating two hybridizing oaks (Quercus spp.). Molecular Ecology 14(2):549-561.

Neophytou C, Aravanopoulos FA, Fink S, Dounavi A (2010). Detecting interspecific and geographic differentiation patterns in two interfertile oak species (Quercus petraea (Matt.) Liebl. and Q. robur L.) using small sets of microsatellite markers. Forest Ecology and Management 259(10):2026-2035.

Paetkau D, Calvert W, Stirling I, Strobeck C (1995). Microsatellite analysis of population structure in Canadian polar bears. Molecular Ecology 4:347-354.

Peakall R, Smouse PE (2006). GENALEX 6: genetic analysis in Excel. Population genetic software for teaching and research. Molecular Ecology Notes 6(1):288-295.

Peñaloza-Ramírez JM, González-Rodríguez A, MendozaCuenca L, Caron H, Kremer A, Oyama K (2010). Interspecific gene flow in a multispecies oak hybrid zone in the Sierra Tarahumara of Mexico. Annals of Botany 105(3):389-399.
Petit R, Csaikl U, Bordács S, Burg K, Coart E, Cottrell J, van Dam B, Deans D, Dumolin-Lapčgue S, Fineschi $S$, Finkeldey R, Gillies A, Glaz I, Goicoechea PG, Jensen JS, König AO, Lowe AJ, Madsen SF, Mátyás G, Munro RC, Olalde M, Pemonge M-H, Popescu F, Slade D, Tabbener H, Taurchini D, de Vries SGM, Ziegenhagen B, Kremer A (2002). Chloroplast DNA variation in European white oaks. Phylogeography and patterns of diversity based on data from over 2600 populations. Forest Ecology and Management 156:5-26.

Petit R, El Mousadik A, Pons O (1998). Identifying populations for conservation on the basis of genetic markers. Conservation Biology 12(4):844-855.

Pritchard JK, Stephens M, Donnelly P (2000). Inference of population structure using multilocus genotype data. Genetics 155(2):945-959.

Salvini D, Bruschi P, Fineschi S, Grossoni P, Kjćr ED, Vendramin GG (2008). Natural hybridisation between Quercus petraea (Matt.) Liebl. and Quercus pubescens Willd. within an Italian stand as revealed by microsatellite fingerprinting. Plant Biology 11(5):758-765.

Schwarz O (1993). Quercus L., p. 72-76. In: Tutin TG, Burges NA, Chater AO (Eds.). Flora Europaea. Cambridge University Press, Cambridge.

Scotti-Saintagne C, Mariette S, Porth I, Goicoechea PG, Barreneche T, Bodenes C, Burg K, Kremer A (2004). Genome scanning for interspecific differentiation between two closely related oak species [Quercus robur L. and $Q$. petraea (Matt.) Liebl.]. Genetics 168(3):1615-1626.

Sofletea N, Curtu AL (2007). Dendrology (in Romanian). Editura Universitatii Transilvania, Brasov.

Steinkellner H, Fluch S, Turetschek E, Lexer C, Streiff R, Kremer A, Burg K, Glössl J (1997). Identification and characterization of (GA/CT)n- microsatellite loci from Quercus petraea. Plant Molecular Biology 33:1093-1096.

Tamura K, Dudley J, Nei M, Kumar S (2007). MEGA4: Molecular Evolutionary Genetics Analysis (MEGA) Software Version 4.0. Molecular Biology and Evolution 24(8):1596-1599.

Van Oosterhout C, Hutchinson WF, Wills DPM, Shipley P (2004). Micro-checker: software for identifying and correcting genotyping errors in microsatellite data. Molecular Ecology Notes 4(3):535-538.

Zeng Y-F, Liao W-J, Petit RJ, Zhang D-Y (2010). Exploring species limits in two closely related Chinese oaks. PLoS ONE 5(11):e15529. 